\title{
Agências regulatórias no \\ Brasil: os casos dos setores de telecomunicações, eletricidade e petróleo/gás natural ${ }^{1}$
}

\section{Introdução}

Desde o início da administração do presidente Fernando Henrique Cardoso em 1995, o Brasil tem passado por mudanças radicais nos seus princípios sociais, econômicos e institucionais, comparáveis àquelas vistas em cinqüenta anos antes, durante o período de Getúlio Vargas. Um dos mais importantes aspectos dessa reforma são as emendas constitucionais que tornaram possível não apenas a venda da segunda mais rica empresa estatal, a Empresa de Telecomunicações Brasileiras (Telebrás), mas também confirmaram o compromisso do governo com os postulados de livre mercado e liberalização (Carneiro e Rocha, 1999: 41). Concomitante à privatização, outro processo estava em andamento na administração: a criação de agências especiais e independentes com o objetivo de regular as atividades das empresas de utilidade pública recém-privatizadas. Isso representou não somente uma novidade na práxis administrativa brasileira, que até então tinha se concentrado nos ministérios em Brasília, mas também uma oportunidade de criar de uma só vez três instituições para lidar com regulação. Essas novas instituições, em teoria, autônomas e independentes dos caprichos da política, foram tidas como necessárias para formular, implementar e controlar as políticas gerais para cada um dos setores privatizados.

Este artigo é um estudo comparativo tanto da criação das agências regulatórias para as telecomunicações, eletricidade e petróleo/gás natural: Agência Nacional de Telecomunicações (Anatel), Agência Nacional de Energia Elétrica (Aneel) e Agência Nacional do Petróleo (ANP), como de seu desempenho desde 1998. Mais importante, será mostrado neste
Henrique Flávio Rodrigues da Silveira é mestre e doutorando em Ciência da Informação pela Universidade de Brasília (UnB); e analista do Banco Central do Brasil, com atuação na área de Planejamento e Orçamento.

Contato: henrique.silveira@ bcb.gov.br 
artigo que a Anatel e a ANP têm desempenhado seus papéis de acordo com as expectativas (de promover competição e a defesa dos consumidores) e que a Aneel tem falhado nessa tarefa por conta da ausência de um fator-chave presente nas outras duas.

O artigo está estruturado da seguinte forma. A segunda seção lida com aspectos metodológicos da pesquisa: a justificação dos casos selecionados e a apresentação das variáveis-chave com as quais as agências serão comparadas. A terceira seção trata a questão da regulação em geral, apresentando uma breve análise histórica do assunto, as rationales e problemas da regulação, a reforma regulatória e os tipos de reguladores. A quarta e última parte do artigo lida com a situação regulatória no Brasil: a situação pré-1997, o estabelecimento de agências regulatórias no país, e as situações enfrentadas pelas três agências desde 1999.

\section{Metodologia}

\section{Seleção dos casos}

Uma vez que existem mais de três agências regulátorias em operação no país, além das responsáveis pelas telecomunicações, eletricidade e petróleo/gás natural, é imperativo justificar essa específica seleção de casos.

Além da Anatel, ANP e Aneel, existem na esfera federal agências responsáveis por alimentos e remédios: Agência Nacional de Vigilância Sanitária (ANVS); por serviços privados de saúde: Agência Nacional de Saúde Complementar (ANS); água: Agência Nacional de Águas (ANA); transportes rodoviários e aquaviários: Agência Nacional de Transportes Terrestres (ANTT) e Agência Nacional de Transportes Aquaviários (Antaq); existem também 14 agências estaduais e uma agência municipal. ${ }^{2}$

Há várias razões para as agências supracitadas terem sido excluídas da análise. A pesquisa tem como objeto o estudo de agências regulatórias encarregadas do controle de setores tradicionais de utilidade pública, em que há (ou havia) predominância de empresas monopolistas, barreiras de entrada para potenciais competidores e custos irrecuperáveis (sunk costs). Ademais, o mercado sujeito à regulação era, até a privatização, dominado por empresas estatais com pouca ou nenhuma accountability, tanto ao governo como aos consumidores.

Os casos da ANVS e ANS mostram-se claramente além do escopo da pesquisa. Uma vez que o mercado que regulam não é propenso a monopólios, a entrada de novas empresas é livre e até encorajada pelo fato de não haver custos irrecuperáveis envolvidos. A ANA, a ANTT e a Antaq foram excluídas, pois só recentemente foram criadas. A legislação 
pertinente foi aprovada apenas em julho de 2000 e junho de 2001, e os seus decretos foram publicados em dezembro de 2000 e fevereiro de 2002 , respectivamente. Isso significa que as agências ainda encontram-se na etapa de formação, contratando pessoal etc. Diferentemente das outras agências federais, elas ainda não tiveram oportunidade de agir efetivamente nos seus campos de responsabilidade.

Finalmente, há as agências estaduais e municipais. Sua exclusão deu-se por conta de uma característica do arranjo federativo brasileiro. Ao contrário dos Estados Unidos, por exemplo, as unidades da Federação no Brasil têm poderes limitados. A maior parte das competências legislativas é prerrogativa (privativa) da União, e os Estados detêm apenas poucas delas, consoante o princípio do direito constitucional brasileiro de "competência residual", i.e., apenas aquilo que não é considerado de competência da União é prerrogativa estadual. ${ }^{3}$ A situação se agrava em nível municipal, em que ainda menos prerrogativas são previstas na Constituição. De fato, a Constituição federal brasileira garante ao governo federal competência privativa para legislar sobre energia, telecomunicações e radiodifusão. ${ }^{4}$ Além disso, as agências estaduais têm como função fiscalizar e regular todos os setores - se a legislação federal permitir - não apenas os serviços de utilidade pública, mas também qualquer outro cuja permissão ou concessão para funcionamento dependa do Estado (unidade da Federação), como transporte. Esse aspecto caracteriza essas agências como multissetoriais. As agências regulatórias estaduais foram criadas como órgãos auxiliares que podem, mediante convênios formais com as agências federais, trabalhar como agentes delegados do governo federal nos Estados (Peci, $\mathrm{n} / \mathrm{d}$ : 9). Elas funcionam mais como monitoras e fiscais do que como reguladoras, angariando e fornecendo informações às agências federais. ${ }^{5}$

Em pesquisas qualitativas, em que apenas um pequeno número de casos pode ser observado, a seleção de caso "tem que ser feita de forma intencional, consistente com os objetivos e estratégias da pesquisa" (King, Keohane e Verba, 1994: 139). Ainda, "a própria pesquisa, então, envolve a procura de valores para a variável dependente" (idem, ibidem). O que tentou ser evitado na seleção de casos na presente pesquisa foi a escolha de casos de acordo com o que se quer verificar como resultado final, o que King et al. chamam "a confirmação da hipótese favorita", em que os casos são escolhidos com o intuito de sustentar as conclusões desejadas (idem; 128).

A principal proposta deste trabalho é mostrar que os arcabouços regulatórios para os setores de telecomunicações e petróleo/gás natural foram criados em um ambiente de influências partidárias diminuídas. Isso tornou possível a criação de agências robustas capazes de estabelecer regras pró-competição nos seus respectivos domínios. 
Para demonstrar isso, usa-se o "arranjo de sistema mais semelhante". ${ }^{6}$ Esse arranjo é útil para pesquisas setoriais e também em pesquisas com poucas observações (Landman, 2000: 28). Neste trabalho, cada agência regulatória é uma observação. Essa estratégia torna possível para o pesquisador reconhecer características dos casos em estudo, identificando as características semelhantes e, felizmente, isolando a característica desviante, que é o fator explicativo chave para o diferente resultado. Construindo um arranjo de sistema mais semelhante para descrever as três agências regulatórias e os resultados esperados (ou reais), tem-se algo similar ao exposto no Quadro 1 (ver Anexo).

O Quadro 1 apresenta três características importantes:

1) é falsificável porque é verificável. Ele pode ser contradito se uma nova agência ou as outras duas agências apresentarem o mesmo resultado (variável dependente) que devesse ser exclusiva ao caso desviante. Se isso acontecer, o esquema é rejeitado ou desconfirmado ou mesmo mantido, mas adicionando-se uma exceção e ao mesmo tempo diminuindo a robustez da teoria (Landman, 2000). Se por outro lado, casos/ observações similares ou comparáveis seguirem o mesmo padrão, a teoria é fortalecida;

2) o esquema passou por uma cuidadosa seleção da variável dependente, de forma que ela de fato varie e seja dependente. Pode parecer óbvio, mas em muitos estudos verifica-se que as variáveis não variam; e

3) o esquema é robusto uma vez que a variável dependente (o sucesso da agência medido pelo avanço de regulação pró-competitiva alcançado no respectivo setor) é mensurável. Mesmo considerando o fator competição como de difícil mensuração, suas consequiências não o são.

\section{Variáveis dependentes e explicativas}

As variáveis explicativas usadas no trabalho são: o status jurídico das agências, o elo entre a criação das agências e o programa de privatização, a situação pré e pós-privatização nos setores estudados, como os conselhos de diretores das agências são organizados e o status de seus membros, a fonte de financiamento das agências, a determinação das tarifas e o papel do ministro da área durante a criação das agências. Essa última variável é considerada como o fator explicativo chave. A variável dependente é o sucesso da agência em promover efetivamente regulação pró-competitiva no setor. Tais variáveis serão analisadas em maior profundidade mais adiante no item "As agências regulatórias." 


\section{Regulação}

\section{Perspectiva histórica}

A regulação pode ser identificada de maneira ampla como "o controle contínuo e focado exercido por uma agência pública sobre atividades consideradas importantes a uma comunidade" (Selznick, 1985). Outros sugerem que regulação deve também ser considerada tanto um conjunto específico de regras como, por exemplo, em saúde e segurança; como influência estatal deliberada, como taxação e subsídios; ou finalmente como quaisquer formas de controle ou influência social (Baldwin e Cave, 1999; Baldwin, Scott e Hood, 1998; Meier, 1985; Sappington e Stiglitz, 1987). No primeiro caso, a regulação se mostra na sua forma mais simplificada e se relaciona com a imposição de uma série de regras juntamente com os mecanismos para fazê-las valer. Tais regras fundam-se em aspectos econômicos ou sociais, tais como a proteção dos consumidores em termos de qualidade de alimentos, por exemplo, ou cidadãos em geral, no que diz respeito a externalidades negativas da produção industrial, por exemplo, a poluição. A regulação entendida como influência deliberada do Estado está geralmente ligada à provisão de serviços e bens pelo próprio Estado (empresas estatais são um bom exemplo) ou à criação pelo Estado de condições favoráveis aos agentes privados, possibilitando dessa forma a provisão de serviços e bens.

Regulação, particularmente nos Estados Unidos, refere-se classicamente aos esforços do governo no sentido de controlar preços, produção ou qualidade do produto, em bens e serviços oferecidos por companhias privadas que de outra forma levariam em conta apenas insatisfatoriamente o "interesse público" (Breyer, 1990; Francis, 1993: 2). Na Europa Ocidental, regulação engloba não somente a noção acima, mas também a provisão de bens e serviços pelo próprio Estado. A regulação também pode ser vista como um processo que ordena (pelo menos idealmente) setor ou setores das esferas econômica ou social que têm propensão à desordem e que, por isso, merecem atenção (Clarke, 2000). Por desordem, leiam-se resultados sub-ótimos que aconteceriam sem regulação ou novamente a inobservância de interesses públicos. Clarke também define regulação como "ordenação envolvendo o estabelecimento de uma forma de autoridade para alcançar o gerenciamento prático de interesses conflitantes" (idem, 2000: 5).

Outros estudiosos restringem o conceito de regulação a matérias econômicas, em que a política regulatória funciona influenciando o setor privado dentro de um sistema de dois subsistemas não mutuamente excludentes: incentivos para fomentar decisões econômicas (regulação verde) e desincentivos para evitar decisões econômicas (regulação vermelha), 
principalmente nas áreas de falhas de mercado como monopólios naturais ou externalidades (Vickers e Yarrow, 1989; Baldwin e Cave, 1999).

Pode parecer até então que regulação é um conceito antigo, pelo menos tão antigo quanto o próprio Estado (Baldwin e Cave, 1999; Baldwin et al., 1998; Majone, 1996a; Bernstein, 1955) e que ela pode significar quaisquer formas de intervenção, pública ou privada, tanto na esfera pública como na particular. Isso requer esclarecimentos.

De fato, se entende de regulação como um conjunto de regras estabelecidas por um Estado ou quaisquer outras formas de autoridade, legítima ou ilegítima, pública ou privada, para organizar a sociedade, então regulação remonta aos primórdios da própria sociedade. As sociedades primitivas estabeleceram normas para serem seguidas por todos os membros do grupo (ou pelo menos por sua maioria), bem como sanções a serem aplicadas no caso de transgressão. A velha máxima latina ubi societas ibi ius claramente sintetiza esse fato: onde há sociedade, há direito. Contudo, a tendência para categorizar regulação como legislação, governance, e controle social, e o amplo uso que esses termos podem adquirir, levou Majone a afirmar que o estudo da regulação coexiste com o direito, economia, ciência política e sociologia. Dessa forma, "impedindo o desenvolvimento de uma teoria distinta sobre a questão como um tipo de policy-making" (Majone, 1996a).

A melhor definição de regulação no contex to do presente trabalho será a mesma adotada por Baldwin, que segue: "a promulgação de um conjunto de regras, acompanhada de mecanismos, tipicamente uma agência pública, para monitorar e promover o cumprimento dessas regras" (Baldwin et al., 1998: 3), também conhecida como "estilo norteamericano de regulação" (Majone, 1996a). Esse conceito, contudo, será refinado para incluir, exclusivamente, o conjunto de regras para controlar a provisão de serviços e bens caracterizados como de utilidade pública. Dessa forma, ele incorporará o controle sobre a taxa de retorno norte-americana (em poucas palavras, avaliação de custos e lucros das firmas), mas estará restrito ao setor de utilidades públicas semelhante à visão da Europa Ocidental.

\section{Rationales para a regulação}

Antes de tudo, é importante se perguntar por que se regula. Por que não deixar os agentes privados, produtores e consumidores decidirem sobre a melhor forma de lidar com suas transações? A resposta imediata a isso é que há imperfeições no mercado, que podem levar a resultados econômicos sub-ótimos, em que os processos econômicos não podem ser total e eficientemente utilizados. As clássicas premissas macroeconômicas de um mercado perfeito implicam que há informação abundante e pública disponível aos consumidores no que diz respeito a preços e qualidade dos 
produtos à venda, e que há um grande número de vendedores e compradores

(Viscusi, Vernon e Harrington, 2000). Além disso, para haver um ambiente competitivo perfeito, a troca de bens não deve ser onerosa, o consumo por um indivíduo não pode afetar o consumo de outros (externalidades), e os bens não devem ser de uso comum (Meier, 1985).

Não surpreende que o mundo real contradiz essas premissas. A informação não é um produto gratuito, tanto em termos de acesso como em oportunidade de entender suas tecnicalidades. As empresas adquirem um papel proeminente no mercado e se tornam o único supridor de um produto ou serviço específico. Subprodutos negativos podem ser inerentes ao processo produtivo, cuja contabilidade pode não ter sido considerada nos custos. Essas imperfeições de mercado são detalhadas abaixo.

\section{Monopólios}

Monopólios são o exemplo típico de imperfeição do mercado (Baldwin e Cave, 1999; Breyer, 1990; Francis, 1993; Prosser, 1989; Helm e Jenkinson, 1997; Manzetti, 2000; Mayer, 2001). As situações de monopólio podem ocorrer principalmente em três circunstâncias: quando há apenas um vendedor (provedor) no mercado, quando o produto à venda é o único de seu gênero, tornando-o insubstituível, ou quando há grandes e significativas barreiras, restringindo a entrada de competidores para prover o serviço ou o bem em questão. Nesse último caso, o monopólio pode ser considerado natural. As empresas de utilidade pública são um bom exemplo de monopólio natural. Tome o caso do serviço de água e esgotamento sanitário como exemplo. Dados os enormes custos para construir a infra-estrutura para coletar, limpar, armazenar, distribuir e comercializar água, é economicamente viável construir apenas uma rede de serviços. Isso naturalmente leva a economias de escala e escopo, tornando mais barato apenas para uma firma oferecer o serviço.

Como pano de fundo das inadequações de mercado, há o que se batizou de teoria fundamental de economia do bem-estar (fundamental theory of welfare economics). O teorema propõe que mercados competitivos levam a uma distribuição eficiente de recursos quando um indivíduo pode ser beneficiado sem ao mesmo tempo prejudicar outrem. Essa situação é chamada ótimo de Pareto (Viscusi et al., 2000).

A ausência de competição em um setor de monopólio induz o agente privado a diminuir a oferta e aumentar preços acima do custo de produção. Nesse caso, há uma injusta distribuição de recursos (rent) dos consumidores aos produtores e também há perda de produção quando o preço aos consumidores é mais alto do que o custo mais uma taxa de retorno razoável (Santos, 1990). Logo, o objetivo da regulação nesses casos é criar condições que imitem um mercado competitivo, tanto 
temporariamente (para permitir a entrada de competidores) como permanentemente (no caso de monopólios naturais). Apesar de a regulação e competição poderem ser vistas como substitutas (e nesse caso o aforismo "competição quando possível, regulação quando necessário" é válido - Kay e Vickers, 1990: 224), em muitas ocasiões a regulação é introduzida não como substituto de um mercado competitivo, mas como sua garantia. Esse é o caso de uma grande empresa no mercado, forçando artificialmente os preços para baixo por algum tempo, tornando inviável a sobrevivência de firmas menores e mais fracas: após essas últimas fecharem as portas ou se fundirem com aquela, a firma líder controlará todo o mercado e a situação cairá no exemplo acima de redução de produção com intuito de aumento de preços.

\section{Assimetria de informação}

As assimetrias de informação também representam um exemplo de imperfeição de mercado que exige correção. A questão vai muito além de saber se a razoabilidade de preços de acordo com o custo de produção é uma justa taxa de retorno. Por conta de casos de medicamentos ineficazes a envenenamentos e morte causados por alimentos estragados, as primeiras regulações dos Estados Unidos tinham como preocupação padrões de segurança e requerimentos de etiquetagem para remédios e alimentos. O governo obrigou as empresas a testarem seus produtos e publicizar tal informação aos consumidores, uma vez que eles não possuíam individualmente a capacidade de avaliar a qualidade dos produtos. Essa legislação regulatória representou o primeiro passo de proteção ao consumidor. ${ }^{7}$

Em muitas ocasiões, os consumidores simplesmente não tinham conhecimento do custo real de determinado produto ou serviço, de modo que não podiam realizar uma avaliação sobre se o preço pedido era justo. Isso podia acontecer pelo fato de as empresas não fornecerem suas planilhas de custo devido à estratégia comercial. Por outro lado, mesmo assumindo que o preço fosse justo, o risco de não se avaliar corretamente a qualidade do produto ou serviço permaneceria.

Atualmente, a situação é um pouco mais complicada. A crescente complexidade e sofisticação dos produtos e dos processos produtivos não raramente estão além da capacidade dos consumidores de avaliarem totalmente as conseqüências de suas escolhas. Ademais, ainda que se presumisse que a informação pudesse ser entendida, subsistiria o problema do custo para produzi-la, tanto em termos de adquiri-la como de alocação de tempo para analisá-la em detrimento de outras atividades produtivas. Por outro lado, os incentivos para fornecer informação por parte das empresas podem ser baixos por medo de seus competidores a usarem sem a devida compensação. 
A regulação, nas palavras de Baldwin e Cave, ao tornar a informação mais acessível e precisa, pode proteger os consumidores contra informações inadequadas e suas conseqüências, ao mesmo tempo que pode encorajar o surgimento de um ambiente de mercado competitivo e saudável (Baldwin e Cave, 1999).

\section{Externalidades}

Muito freqüentemente, uma atividade legítima de um indivíduo ou empresa pode incorrer custos a terceiros grupos sem a devida compensação. Como os primeiros não absorvem o custo integral desse efeito negativo, eles terão o incentivo de continuar nessa atividade, senão de incrementá-la.

A poluição é a ilustração mais comum de tal efeito negativo. Na medida que o custo de oferecer um determinado produto não internaliza o custo da degradação ambiental (rios, cidades e ares poluídos), mais interessante será manter a produção e, inversamente, a produção mediante processos menos poluidores será mais cara e menos atraente. Esse e o clássico problema dos bens difusos (tragedy of the commons), descrito com detalhes por Hardin (Hardin, 1968; ver também Ostrom, 1994). ${ }^{8} \mathrm{Na}$ sua opinião, recursos disponíveis a todos, tais como a atmosfera e as bacias fluviais, tentam seus usuários abusarem no uso como se ilimitados fossem, em um ambiente de recursos finitos. Ainda com relação a bens difusos, Ostrom e Walker indicam que, sem alguma forma de coordenação ou organização que permita aos indivíduos concordar em padrões de consumo, apropriação, monitoramento e penalidades, os recursos serão superutilizados (Ostrom e Walker, 1997). Logo, regulações em forma de políticas pró-ambientais, impostas por agências governamentais (ou não necessariamente governamentais mas com seu aval), forçam a absorção dos custos dos mecanismos antipoluição na cadeia produtiva, ou impõem multas ao poluidor, conforme o princípio "poluidor".

Se no mercado houver grande número de firmas competindo por clientes, o cumprimento dessas regras as forçariam a ser eficientes ou a descobrir nichos mercadológicos, por exemplo, apelando aos consumidores ambientalmente conscientes. Contudo, se as externalidades estiverem conjugadas a uma situação de monopólio, em que os consumidores não têm opções, então a empresa passará os custos das multas ou do equipamento antipoluição ao preço final cobrado ao consumidor. Em tal situação extrema, os reguladores teriam que lidar com o monopólio, a externalidade e com a determinação do preço.

\section{Comportamento anticompetitivo}

Esse tipo de comportamento acontece quando empresas agem de forma não condizente a um ambiente saudável de competição. As empresas 
que têm uma fatia importante no mercado cortam seus preços abaixo do nível de custo para forçarem seus competidores a saírem da praça. Uma vez que esses concorrentes vão à falência ou se fundem com a firma dominante, os preços sobem bem acima dos custos em detrimento dos consumidores, primeiramente para recuperar as perdas pelos preços baixos anteriores e posteriormente para extrair rendas. Esse tipo de comportamento é chamado de predatório, dumping ou de competição excessiva nas palavras de Breyer (Breyer, 1990). Baldwin e Cave ressaltam que uma precondição para a empresa tomar parte em tal atividade predatória é a capacidade financeira para financiar as perdas durante a "promoção de preços" (Baldwin e Cave, op. cit.).

$\mathrm{O}$ que a regulação procura evitar é a tentativa de monopolizar ou mesmo conspirar com vistas ao monopólio (Viscusi et al., 2000). O problema para os reguladores em situações como essa é diferenciar a posição dominante de uma firma como consequiência de processos de produção melhores e mais eficientes daquela que é decorrente de práticas predatórias.

Um exemplo clássico de comportamento predatório levando à monopolização foi o da Standard Oil Company nos Estados Unidos. Os proprietários da empresa, a família Rockefeller, construíram seu império mediante a compra de mais de 120 rivais, tanto por meio de falências forçadas como mediante controle dos oleodutos e das ferrovias (dois outros exemplos de monopólio natural), prejudicando a capacidade das rivais de serem competitivas. De fato, em meados de 1890, a companhia holding detinha mais de $90 \%$ da capacidade de refino e venda de petróleo e derivados (Viscusi et al., 2000). Esse foi um exemplo extremado, que instou uma pronta resposta regulatória por parte do governo norte-americano.

\section{Problemas com regulação}

Apesar dos méritos que a regulação pode ter ao assegurar a saúde e a segurança das pessoas, ou ao proteger os consumidores de preços predatórios e comportamentos monopolísticos, a questão está longe de apresentar consenso. A crítica se concentra em quatro principais pontos: ineficiência, captura, declínio na capacidade competitiva das empresas e desincentivo à inovação; juntamente com o perigo de excesso de regulação e legalismo (Francis, 1993; Meier, 1985; Ayres e Braithwaite, 1992; Bardach e Kagan, 1982; Eisner, 2000; Navarro, 1985; Vickers e Yarrow, 1989).

\section{Ineficiência}

A ineficiência se traduz na percepção de que a regulação será mais nociva do que benéfica à condição geral da economia (Eisner, 2000). O Estado é considerado como inerentemente incapaz de atingir objetivos 
regulatórios de maneira eficiente. Uma miríade de diferentes regras é estabelecida, demandando pessoal qualificado para verificar e avaliar o cumprimento das normas de regulação, e também para impor multas e outras penalidades em caso de não observância. Quanto a esse último aspecto, existe também o custo potencial de litígios judiciais, levando ao desperdício de recursos escassos tanto para o governo como para a indústria regulada.

Antes de pôr um produto à venda no mercado, a empresa tem que satisfazer inúmeras exigências em termos de padrões de ingredientes, adição de conservantes e datas de validade. Essas exigências são cumpridas não só pela firma, mas também têm que ser checadas pelo órgão regulador. Esse procedimento de dupla checagem é lento e caro, e quando multiplicado pela quantidade de diferentes produtos disponíveis nos supermercados nos dá uma idéia de quão ineficiente e custoso todo o processo pode se tornar.

Críticos argumentariam que a auto-regulação seria uma solução mais apropriada e eficiente para o problema. Por meio da auto-regulação, as empresas estabeleceriam seus padrões de produção e elas próprias fariam a checagem. Um bom exemplo de auto-regulação acontece quando o produto à venda recebe um selo de qualidade ou garantia pela associação das indústrias alimentícias. Levar esse selo no rótulo mostraria ao consumidor que o produto teria passado por um processo de controle de qualidade. Uma abordagem diversa na auto-regulação seria autorizar a outra organização, um laboratório de idoneidade reconhecida, a tarefa de avaliar a qualidade do produto. Em ambos os casos, as empresas estariam oferecendo um produto de alta qualidade sem incorrer no fardo de normas regulatórias, e o Estado estaria livre desse processo custoso de avaliação e dupla checagem.

\section{Captura}

Alguns analistas em regulação afirmam que, se por um lado, as demandas para a criação de um arcabouço regulatório podem surgir como resposta às falhas de mercado, por outro, a regulação pode ser usada de maneira a proteger os interesses das indústrias do setor, em vez de promover um ambiente saudável de competição ou a proteção dos consumidores. Esse tipo de comportamento é conhecido como captura da agência (agency capture) ou proteção do produtor.

O relacionamento "íntimo" que naturalmente se estabelece entre reguladores e regulados, mesmo quando propício a problemas, pode levar à captura dos primeiros. Uma vez que os reguladores terão que se basear de uma forma ou de outra na informação fornecida pelos regulados, alguma forma de cooperação deve ser desenvolvida. Isso pode dar às empresas reguladas, nas palavras de Baldwin e Cave, "um grau de manipulação 
sobre os procedimentos regulatórios, o que, com o tempo, produz captura" (Baldwin e Cave, op. cit.: 36).

Os reguladores também são suscetíveis à captura porque eles podem ter perspectivas de emprego no setor que regularam após deixarem seus postos, não apenas trabalhando para a empresa regulada, mas também em escritórios de advocacia e consultorias dedicadas à defesa da indústria regulada. Nesse caso, eles tenderiam no extremo a adotar políticas regulatórias favoráveis à indústria regulada, ou no mínimo a serem lenientes no cumprimento de comandos regulatórios. Esse tipo de regulador é chamado de "carreirista"(Wilson, 1989), que está esperando por sua "propina retroativa" - delayed bribery (Quirk, 1981). Uma possível solução para evitar esse problema seria a adoção de quarentenas aos servidores ao terminarem seus mandatos de reguladores, com a proibição de trabalharem no setor que regularam por um determinado período de tempo.

\section{Declínio de competitividade}

Os críticos da regulação também argumentam que todas essas normas regulatórias conduzem a um declínio na competitividade industrial por conta de seu custo para a indústria, e em conseqüência, para os consumidores (Meier, 1985). Isso é mais comum quando os reguladores proíbem que a empresa sob regulação lucre com o uso de processos mais eficientes de produção, ou de materiais mais baratos e tecnologicamente avançados, que diminuiriam os custos gerais e aumentariam o faturamento da firma.

Uma das razões por trás das normas regulatórias é que, se as empresas se aproveitarem sem controle dos benefícios advindos de técnicas inovadoras, elas podem adquirir uma vantagem que a longo prazo pode levar a poderes de monopólio, com todas as consequiências negativas que isso representa. Por outro lado, contudo, ao levarem isso em conta de antemão, a indústria sob regulação tem menos ou nenhum incentivo para inovar, novamente em detrimento dos consumidores. Esse é um dilema importante para a regulação: proteger os consumidores contra a ameaça de monopólio, ou dar à indústria livre poder para inovar e tornar-se mais eficiente, não necessariamente distribuindo à sociedade os benefícios que disso advenham.

Certamente, há estratégias intermediárias que tendem a minimizar os custos desse dilema. Dentre as possíveis soluções pode-se mencionar o uso de mecanismos de controle de preços (o mais conhecido é o chamado índice Retail Price Index - RPI-X) ou o estabelecimento de um período de tempo durante o qual a empresa pode auferir os lucros de sua inovação, de maneira semelhante a uma licença de patente. No primeiro caso, o índice é usado majoritariamente para empresas em situação de 
monopólio natural, tendo sido criado em um primeiro momento durante as discussões acerca do arranjo regulatório que deveria preceder à privatização do setor de telecomunicações no Reino Unido, e posteriormente estendido a outros serviços de utilidade pública nesse país (Baldwin e Cave, 1999: 226). Nesse caso, o preço de um produto ou cesta de produtos é estabelecido de antemão para um determinado período, geralmente cinco anos, sendo os reajustes baseados em um valor $\mathrm{X}$ descontado do índice de inflação ao consumidor $(R P I)$. Dessa forma, se a fórmula de reajuste ficou estabelecida em $R P I-5$ e a taxa de inflação for de 5\%, ter-se-á $5-5=0$, isto é, nenhum aumento será permitido e maiores rentabilidades para a firma serão conseguidas por meio de diminuição de custos e eficiência.

\section{Excesso de regulação}

Outra crítica feita contra-regulação é o perigo de seu excesso. A conjectura por trás disso é que na evolução das normas regulatórias podem ser adicionadas uma miríade de regras detalhadas, complexas e por vezes desnecessárias, acarretando confusão. Isso tem efeitos negativos tanto para os reguladores como para os regulados, pois estes têm que cumprir com uma selva de normas e aqueles têm que monitorar o seu cumprimento.

Esse excesso de regras pode ser causado, entre outras razões, pela própria natureza da burocracia dentro da administração ou da agência regulatória, de querer incrementar sua importância e seu caráter "insubstituível”, o que não é novo para a teoria das organizações. À pergunta "o que a burocracia quer?", Wintrobe responde que os burocratas querem maiores dotações orçamentárias, influência na elaboração de políticas públicas, poder, ou simples utilidade (Wintrobe, 1997: 431), e isso é o que efetivamente acontece quando as normas regulatórias são abundantes e complicadas o bastante para que apenas os burocratas (ou outros especialistas) tenham o conhecimento da hermenêutica da regulação. O conceito de que a burocracia constrói um império de poder (empire building) dentro de uma abordagem de maximização de utilidade foi formalizado por William Niskanen (Niskanen, 1968).

Outra explicação para entender o excesso de regulação está na tentação de desenhar regras superabrangentes capazes de abarcar o maior número de casos possíveis para sua aplicação. Isso não apenas multiplicou as regras, mas também o número de órgãos regulatórios, não raramente com justaposição de competência.

\section{A reforma regulatória}

Em meados da década de 70, aqueceu-se o debate de como a regulação estava afetando negócios e a economia do hemisfério ocidental, principalmente nos Estados Unidos (ver em relação aos Estados Unidos, 
Bardach e Kagan, 1982; e à França e ao Reino Unido, Majone, 1996b: 47-48). As normas regulatórias começaram a ser vistas como um fardo não razoável à iniciativa privada, excedendo, em muito, os benefícios que a sociedade e os consumidores em geral receberiam. A dificuldade estava em como reconciliar a necessidade de eficiência e competitividade com o desejo de preservar os ganhos sociais que a correção das falhas de mercado teria trazido (Moran, 1989: 50).

O movimento para reformar o esquema regulatório ou para “desregular" tem sido usado desde então como mote para diversas modificações tanto nas instituições da regulação como nas próprias regras. Como Moran e Prosser observam, em alguns casos essas mudanças representaram a saída do Estado de atividades produtivas via privatização e em outros contextos isso requereu a criação de novas instituições regulatórias e a elaboração de novas normas regulatórias (Moran e Prosser, 1994:9). Poucos foram os países que tomaram apenas uma dessas alternativas, sendo a política mais adotada na reforma regulatória uma mistura das duas.

No contexto norte-americano, a reforma regulatória, no seu início, compreendeu a "desregulação" de setores que eram estruturalmente competitivos, como o de aviação civil (Breyer, 1990), mas que na era Reagan passou a incluir a então chamada "regulação social", i.e., proteção ao meio ambiente, saúde pública e questões de defesa do consumidor (Harris e Milkis, 1989:6). Defensores da desregulação julgavam que excessivas e pouco razoáveis normas regulatórias eram responsáveis por grande parte do declínio econômico do final dos anos 70 (idem, 1989: 22). Entre as modificações engendradas no início dos anos 80 estavam a transferência da política regulatória do Congresso para o Executivo, uma diferente abordagem quanto às nomeações dos presidentes das agências regulatórias e uma política orçamentária restritiva (com diminuição de responsabilidades e corte de pessoal).

No contexto da Europa Ocidental, o processo de desregulação foi decorrente da impaciência com o mau desempenho das empresas estatais, inicialmente no Reino Unido e posteriormente no resto do continente, e esse processo é geralmente associado à privatização e liberalização (Weyman-Jones, 1994).

A América Latina, em geral, e o Brasil, especificamente, ficaram para trás neste debate. Hiperinflação, moratórias, crescente perda da capacidade do Estado de cumprir seu papel, em vez de acelerarem as tentativas de mudança, apenas atrasaram a reforma. De fato, com exceção do Chile, os países da América Latina apenas começariam a desregulação e a privatização nos anos 90. A primeira leva de países a adotar a desregulação aconteceu no início da década com mudanças na Argentina e no México (1990) e Venezuela (1991). A segunda aconteceu em meados 
da década e alguns ajustes foram feitos no Peru (1994), Bolívia (1995) e Panamá (1997). Por fim, o Brasil (1997-1998) foi o último dos grandes países a embarcar em uma reforma regulatória (Wellenius, 2000). A reforma regulatória traduziu-se em privatização e, no caso das estatais provedoras de serviços caracterizados como monopólios naturais, tais como telecomunicações e eletricidade, combinou-se privatização com novas instituições regulatórias. Um novo regime regulatório tinha que ser posto em prática de forma a facilitar a transferência de propriedade das empresas, uma vez que se ganhava apoio político e assegurava-se a confiança de outros setores na economia, principalmente dos potenciais compradores das empresas, e dos consumidores, que poderiam temer a criação de monopólios privados (Francis, 1993: 33).

Pelo exposto acima, fica claro que tanto na Europa Ocidental como nos Estados Unidos, as mudanças regulatórias ou a desregulação significaram uma transformação nas estruturas regulatórias tradicionais, não um fim à regulação. A desregulação não representou necessariamente uma reforma quantitativa no número de normas (apesar de uma racionalização de fato ter ocorrido), mas sim uma mudança qualitativa em como a regulação deveria ser feita e em que setores isso deveria acontecer (Harris e Milkis, 1989: 48). Majone chamou essa prática de uma combinação de desregulação com re-regulação, e Hancher e Moran, a redefinição do espaço regulatório (Majone, 1990: 3; Hancher e Moran, 1989: 277).

\section{Instituições regulatórias no Brasil: reforma para credibilidade?}

\section{A situação pré-1997}

Antes de 1997, não havia agências regulatórias nos moldes como elas existem hoje. O Ministério das Comunicações e o Ministério das Minas e Energia eram os responsáveis em Brasília não apenas pela formulação de políticas de telecomunicações e energia (eletricidade e petróleo gás natural), mas também pelo monitoramento do progresso dessas políticas, executadas pelas estatais Telebrás, Centrais Elétricas Brasileiras (Eletrobrás) e Petróleo Brasileiro S/A (Petrobras), diretamente ou via suas subsidiárias. Essas companhias, apesar de formalmente subordinadas a seus respectivos ministérios (e em última instância à Presidência da República), eram pouco accountable ao governo. O que importava a este último era que as estatais controlassem os preços sob sua jurisdição. Dessa forma, ajudando a controlar (mesmo que artificialmente) as taxas de inflação, não raro em detrimento da capacidade financeira dessas empresas. Elas tinham uma burocracia forte, tanto na administração como 
fora dela, e suas pastas gerenciavam fundos da ordem de dezenas de

bilhões de dólares. Os usuários, tantos os industriais como os residenciais, não dispunham de fóruns para reclamações para os maus serviços (telefones que não funcionavam, chamadas de longa distância de alto custo, filas para obtenção de uma linha que duravam anos, impossibilidade de recebimento de indenização em caso de falha no serviço de eletricidade, entre outros). A única saída de protesto contra as três companhias era o sistema judicial, caro e lento.

Mas isso retrata apenas o lado do consumidor. Financeiramente, com exceção da Petrobras, as companhias estavam chegando ao limite do seu sistema de financiamento, que era tão intensivo em capital, para fazer em face das demandas de novos consumidores e de atualização da rede para tecnologias mais eficientes e modernas. Os sistemas de eletricidade e telecomunicações estavam chegando ao limiar da exaustão.

A necessidade de reforma do Estado ganhou destaque durante a campanha presidencial de 1994 (após as tentativas frustradas ou incompletas iniciadas por Collor em 1990), e de fato, após tomar posse no ano seguinte, o novo presidente delineou a estrutura dessa reforma. O plano não apenas englobava uma mudança na administração federal, mas também vislumbrava uma nova forma de o Estado e outros agentes proverem serviços públicos. Isso ajustou o passo de outra onda de privatizações. ${ }^{9}$

A perspectiva de privatização de importantes empresas responsáveis pela oferta de serviços de utilidade pública, contudo, demandava uma nova abordagem à regulação. O temor era de que privatizar monopólios públicos sem montar uma estrutura de monitoramento e controle dos serviços apenas significaria a mudança de um monopólio público para um privado, com todos os problemas que isso incorreria como visto nos itens acima. Até mesmo deputados e senadores que não aprovavam os planos de privatização perceberam que alguma forma de controle deveria existir, e apresentaram com esse intuito seus próprios projetos de lei para a criação de órgãos regulatórios.

Uma questão levantada na época foi: por que não deixar o processo regulatório sob a responsabilidade do ministério da área? Por que não deixar com o Ministério das Comunicações e com o Ministério das Minas e Energia essa tarefa? Por que criar outro grupo burocrático dentro da administração federal, com todos os custos que isso acarretaria?

Há três respostas possíveis para tal:

1) a própria reforma administrativa;

2) uma estratégia de blame shifting; e

3) credibilidade.

Como mencionado acima, a própria burocracia estava sob escrutínio pelo novo governo, e acreditava-se que a criação de novas estruturas para a regulação da forma tradicional (um departamento inserido na 
estrutura de um ministério) iria contra o ethos da reforma. Novas, mais

ágeis e modernas instituições eram necessárias, e as agências regulatórias satisfaziam a esse requisito (Brasil, 1995; Bresser Pereira, 1998a e 1998b). O Quadro 3 (ver Anexo) descreve brevemente os objetivos da reforma do Estado no país (as setas indicam o sentido das mudanças propostas).

A reforma administrativa, parte de uma ampla reforma do Estado, tem por pressuposto a existência de quatro setores distintos no Estado: o núcleo, atividades privadas do Estado, os serviços não-exclusivos e finalmente o setor de produção de bens e serviços (idem, ibidem). O núcleo é um setor relativamente pequeno, composto pelos Poderes Executivo (presidência e vice-presidência), Legislativo e Judiciário, juntamente com o Ministério Público e o Tribunal de Contas da União. As atividades privadas do Estado seriam desempenhadas por órgãos descentralizados do Estado e incluiriam os serviços de seguridade social, forças policiais, reguladores e controladores das atividades realizadas pelo setor privado. Os serviços não-exclusivos incluiriam atividades promovidas tanto pelo Estado como pela iniciativa privada, e neles incluemse educação universitária, serviços médicos, centros de pesquisa etc. Finalmente, há o setor que produz bens e serviços que são normalmente comercializados no mercado. Um bom exemplo desse último setor são as empresas estatais que produzem e vendem produtos no mercado. Para esse setor, a reforma propunha a venda de tais firmas para ganho de eficiência e diminuição do fardo fiscal do Estado.

Fica claro que a criação de agências regulatórias no contexto da reforma administrativa cumpria dois fins: ter um órgão livre das velhas e tradicionais práticas dentro da administração; e monitorar de perto as empresas recém-privatizadas (ou perto de serem).

A estratégia de blame shifting, apesar de em si mesma insuficiente como base teórica para mudança tão drástica na tradição da administração pública brasileira, não é inédita na arena política (Fiorina, 1982; McCubbins et al., 1987). ${ }^{10}$ Ao criar uma agência com um status diferente dentro do governo, em que a influência política seria explícita e propositalmente diminuída, se algo de errado acontecesse no ambiente pósprivatizado, com falhas nos serviços, o governo (ou o Legislativo) poderia lavar suas mãos e afirmar que a agência se compunha de especialistas na área e que teoricamente sabiam o que estavam fazendo, tendo inclusive à disposição os instrumentos legais para "prevenir" ou "corrigir" tais falhas. Nas palavras de Fiorina, ao outorgar a uma agência a responsabilidade pela implementação de uma atividade regulatória, legisladores não apenas evitam o problema de tomar decisões específicas, como também evitam, ou pelo menos disfarçam, sua responsabilidade pelas conseqüências em última instância das decisões efetivamente tomadas (Fiorina, 1982: 47). 
Finalmente, mais importante na presente análise é o papel de credibilidade que o governo queria transmitir. O governo quis deixar claro aos potenciais investidores que as regras não seriam mudadas por conta de caprichos políticos (para agradar consumidores ou outro grupo políticoeconômico) ou razões macroeconômicas (controle de preços para controlar inflação), de forma a extrair rendas das indústrias reguladas indevidamente. Em outras palavras, o governo queria garantir o cumprimento contratual. Não raro aconteceram quebras de contratos que minaram a credibilidade do governo perante investidores. A criação de agências regulatórias "independentes" permitiria atrair mais investimentos e maximizar as rendas da privatização.

Levy e Spiller afirmam que um arranjo regulatório com credibilidade e eficácia, e sua conseqüente capacidade de atrair investimentos e favorecer eficiência na produção e uso de serviços, varia de acordo com as instituições políticas e sociais de cada país, em suas palavras, varia de acordo com "a dotação institucional do país", tais como os tribunais, normas informais, e as capacidades administrativas do país (Levy e Spiller, 1996:4). A evidência que eles fornecem sugere que compromissos para um regime regulatório com credibilidade pode ser cultivado mesmo no que aparenta ser um ambiente problemático, e que sem tais compromissos, investimentos de longo prazo dificilmente acontecerão. Experiências passadas no Brasil mostram a investidores (e aos consumidores em geral) que os canais institucionais comuns de regulação, i.e., via ministérios, não merecem confiança dada à falta de credibilidade. Para complicar a situação, o sistema judiciário do país é complexo, caro e repleto de falhas, o que pode ter um efeito deletério ainda mais sério.

Levy e Spiller argumentam que políticas regulatórias de sucesso encorajarão tanto o investimento privado como uma eficiente provisão de serviços. Esse argumento baseia-se no desenvolvimento de uma estrutura de governance regulatória que limita ações administrativas arbitrárias, o que atrai investimentos e promove eficiência. A capacidade institucional e os requerimentos de governance regulatória influenciam as estruturas de incentivos regulatórias que são viáveis em determinados países ou setores (Levy e Spiller, 1996: 14).

Essas garantias e salvaguardas são necessárias, e as agências regulatórias foram consideradas como a melhor resposta para satisfazer às demandas dos investidores. Certamente, poder-se-ia esperar que essas garantias fossem colocadas em prática antes da venda das empresas estatais, de forma que todo o arcabouço regulatório estivesse em operação quando a privatização ocorresse. Curiosamente, as companhias de eletricidade começaram a ser privatizadas antes das mudanças regulatórias propostas pelos consultores contratados pelo governo federal (Coopers e Lybrand, 1997a e 1997b), antes dessas propostas serem aceitas (na sua 
maioria) e transformadas em lei, e mesmo antes da criação e funcionamento da agência regulatória do setor. Em julho de 1995 e maio de 1996, o governo federal leiloou, com sucesso, duas empresas de distribuição de eletricidade, Espírito Santo Centrais Elétricas (Escelsa) e Empresa de Energia Elétrica do Rio de Janeiro (Light), respectivamente. Em novembro de 1996, a Companhia de Eletricidade do Rio de Janeiro (Cerj), empresa estatal estadual, foi privatizada. São Paulo e Rio Grande do Sul seguiram os passos e ainda em 1996 e em 1997 privatizaram suas companhias. A agência regulatória para o setor, a Aneel, foi criada apenas pela lei no 9.427 de dezembro de 1996 e regulada pelo decreto $\mathrm{n}^{\circ} \mathbf{0} 2.335$ de outubro de 1997.

Hill e Abdala afirmam que a existência de um regime regulatório estável e crível antes da privatização aumenta o valor da firma para compradores potenciais ao reduzir o risco associado à compra (Hill e Abdala, 1996: 203). Se esse for de fato o caso, os investidores que adquiriram as empresas brasileiras distribuidoras de eletricidade devem ter achado o negócio uma barganha irresistível para assumirem o risco de reveses nas suas expectativas empresariais.

Pereira e Mueller constroem um modelo para explicar como as preferências do legislador (nesse caso o presidente, uma vez que é ele quem envia ao Congresso um projeto de lei ou uma medida provisória que dá início ao processo legislativo) são traduzidas em última instância na lei (Pereira e Mueller, 2001; cf também Mueller, 2001). O modelo proposto assume que o presidente tem preferências claras no que concerne aos resultados que ele gostaria de ver como conseqüência das ações da agência reguladora. Essas preferências são tidas como dadas e assume-se que surgem como forma de maximização do apoio político ao presidente, que leva em conta como os diferentes resultados afetam os vários grupos na sociedade e como esses grupos respondem em termos de apoio e oposição. O presidente precisa determinar aqui três aspectos:

1) a estrutura e os procedimentos da agência, o que em outras palavras significam o desenho da agência;

2) o chefe da agência; e

3) a posição inicial da política regulatória. ${ }^{11}$

Se o custo da credibilidade é baixo, o presidente tenderá a nomear seu regulador favorito em termos políticos, e sua posição política inicial estará mais perto de sua preferida. Se, por outro lado, o custo da credibilidade é alto, o presidente nomeará como reguladores aqueles a quem o mercado considera mais tecnicamente qualificado e politicamente neutro, e o mesmo se aplica à posição política inicial.

Ainda, segundo o modelo dos autores, poder-se-ia esperar que os desenhos das agências e as posições iniciais da política regulatória fossem 
diferentes de acordo com as especificidades do setor regulado. Uma

observação mais detalhada, contudo, mostra que a estrutura das agências em análise nesse trabalho varia muito pouco. Os próprios autores reconhecem que se o modelo apresentado é uma boa ilustração do processo regulatório, poder-se-ia imaginar que as agências criadas variariam para cada um dos setores, tanto em termos de desenho como de preferências regulatórias. Pereira e Mueller sugerem que esse “"isomorfismo' (...) decorre da falta de experiência (regulatória do governo) e do curto período de existência das agências, e que essa situação não está em equilíbrio" (Pereira e Mueller, 2001: 4). Como corolário do exposto, espera-se que provavelmente algumas características das agências mudem durante o curso de sua atuação e que se ajustem às diferentes características do setor regulado.

Estou de acordo com a conclusão dos autores que a falta de experiência em regulação, juntamente com a pressa do governo em acertar o passo da reforma e mostrar aos investidores seu compromisso em não se apropriar de rendas que as firmas possam vir a ter, possa ter contribuído para a similitude das agências. Todavia, passo a analisar no item seguinte outra variável que tem sido negligenciada na literatura até então: o papel e a influência dos ministros das áreas durante e após a criação das agências.

\section{O ambiente político durante a criação do novo arcabouço regulatório}

Dadas as regras eleitorais do país, é bastante difícil para um partido obter sozinho a maioria absoluta das cadeiras no Congresso Nacional, donde a necessidade de formar uma coalizão legislativa. ${ }^{12}$ A coalizão de 1994 e 1998 incluía o partido do presidente, o PSDB, o PMDB, o PFL, o PTB e o PPB. Essas cinco agremiações garantiam votos mais do que suficientes para que o Executivo aprovasse quaisquer (ou a maioria) dos projetos de lei no Congresso. Como parte do arranjo dessa coalizão, a administração organizou a "partilha" de postos temporários (de confiança), incluindo as posições de ministro e secretários executivos. Não obstante, o presidente manteve o que posteriormente se chamou de "quota pessoal", postos para os quais seriam nomeadas pessoas de sua confiança pessoal, não indicadas pelos diversos partidos (houve mudanças menores nessa quota desde 1995, mas o princípio foi mantido). Como exemplos dessa quota pessoal, em uma lista não exaustiva, tem-se o Ministério das Relações Exteriores, o da Fazenda, o da Educação e o das Comunicações; por outro lado, o Ministério dos Transportes, Agricultura, Previdência Social, Integração Regional e que o deMinas e Energia, que pertencem à quota partidária. Ademais, cada partido tem sua pasta tradicional: Transportes e Integração Regional, PMDB; Agricultura, PTB; e Previdência Social e Minas e Energia, PFL. 
O presidente em 1995 nomeou como ministro das Comunicações o engenheiro Sérgio Motta, com a incumbência de reorganizar todo o setor das telecomunicações do país, inclusive o serviço postal, preparando a Telebrás para ser privatizada, e também a criação da Anatel como agência regulatória da área. Ele pôs em ordem todo um novo arranjo regulatório para as telecomunicações brasileiras. Sua idéia original era a de reduzir drasticamente o Ministério das Comunicações a um mínimo, apenas mantendo um núcleo formador de políticas para a área, e transferir todas as outras competências para a Anatel (O Estado de São Paulo, 2001a e 2001b).

A situação do Ministério das Minas e Energia era bastante diferente. O ministério era "domínio" do PFL e todos os ministros indicados à posição pelo presidente (menos o último e atual) eram provenientes do partido: Raimundo Brito (1º de janeiro de 1995 a 31 de dezembro de 1998), Rodolfo Tourinho (1º de janeiro de 1999 a 23 de fevereiro de 2001) e José Jorge (13 de março de 2001 a 8 de março de 2002).

Em ambas as áreas, contudo, as agências regulatórias foram criadas como entes independentes, e apesar de manterem um diálogo constante e próximo com os policymakers dos ministérios, não eram subordinadas a esses. No setor de petróleo/gás natural, apesar de estar sob a égide do Ministério das Minas e Energia, o presidente conseguiu indicar para o posto de diretor-geral da agência alguém de sua total confiança, David Zylberstein, um técnico notório não só por sua competência na área, mas também por ser, então, genro do presidente.

Na prática, o que isso representou foi que o Ministério das Comunicações pôde introduzir com menos pressões políticas as mudanças no setor que tinham sido propostas. Evidentemente, isso não significa que não houve pressões, ${ }^{13}$ apenas que o ministro responsável foi mais poderoso e hábil do que o outro, porque estava diretamente amparado no presidente e não nos partidos. O primeiro diretor-geral da Anatel em 1997 (reconduzido em 2001), Renato Guerreiro, tinha sido secretárioexecutivo do ministério, o segundo cargo mais importante na hierarquia no órgão depois apenas do próprio ministro. A ANP foi um caso intermediário, todavia a legislação regulatória aprovada (incluindo uma emenda constitucional que quebrava o status monopolista da Petrobrás) tornou possível a abertura do setor à competição.

Por outro lado, a Aneel foi um fracasso. A reforma do setor, tanto em termos de privatização das geradoras federais como em termos da regulação, não decolou e o setor ficou órfão e sem um ambiente regulatório crível.

\section{As agências regulatórias}

No período de aproximadamente um ano, as três agências tinham sido criadas e começaram a se organizar em termos de facilidades físicas 
e de pessoal. A primeira foi a Aneel, criada pela lei no 9.427 de dezembro de 1996. Em julho de 1997, a indústria de telecomunicações foi regulada pela lei no9.472 e em outubro de 1997, a Anatel foi criada. Finalmente, a lei no 9.478 de agosto de 1997 criou a agência de regulação de petróleo/gás natural, ANP. O Quadro 4 (ver Anexo) mostra as características-chave das três agências regulatórias. Ele é uma versão estendida do Quadro 1 e apresenta o arranjo de sistema mais semelhante.

Todas as agências, dentro do novo ethos da reforma na Administração Pública Federal, foram criadas como autarquias federais de natureza especial, o que lhes dava status de órgão público, mas seguindo regras diferentes do resto da administração. Isso significa que, apesar de seguirem os princípios constitucionais no que concerne à administração pública, elas seriam independentes. Essa independência traduz-se na prática pelas seguintes características:

1) os diretores das agências não são administrativamente subordinados a nenhum ministério (Fazenda, Planejamento), mesmo o ministério do setor;

2) a prerrogativa de nomear diretores é exclusiva do presidente, com aprovação do Senado Federal. Apenas em casos de crime ou renúncia podem esses diretores ser removidos do cargo antes do término legal do mandato;

3) a agência tem liberdade de determinar tarifas para a maioria dos serviços $;^{14} \mathrm{e}$

4) as agências têm suas próprias dotações orçamentárias. ${ }^{15}$

A última variável independente é o papel do ministro da área durante a criação da agência. Não é surpresa imaginar que a criação de tais agências não foi trivial ou consensual, uma vez que sua existência e o resto da legislação regulatória significariam uma grande mudança na administração federal e na forma como recursos públicos e privados são distribuídos. Como sugerido acima, para a Anatel e ANP, o arcabouço regulatório foi criado com menos pressões partidárias, diferentemente do setor elétrico cuja legislação regulatória foi enfraquecida por politicagem e influência partidária. Tal variável é apresentada como o fator explicativochave para entender os diferentes resultados em termos de promoção de competição, como mostrado na última linha do Quadro 4. As agências tinham que lidar com setores que eram monopólios, e essa característica mudou, com diferentes nuances, após o programa de privatização. No que diz respeito às telecomunicações, o monopólio da Telebrás foi quebrado e substituído por um duopólio nas linhas fixas (de 1998 a 2003) ${ }^{16} \mathrm{e}$ três ou quatro firmas no mercado de telecomunicação móvel (duopólio de 1997 a 1999, com abertura e total a partir de 2003). A agência de eletricidade supervisionou a venda de companhias de distribuição (apesar de algumas terem sido vendidas antes da criação da Aneel, como já afirmado 
acima), que detêm o monopólio da atividade e a venda das principais companhias geradoras estaduais, mas não as federais. Quanto ao petróleo/gás natural, o setor foi profundamente modificado com a emenda constitucional que pôs fim ao monopólio de meio século da Petrobrás na exploração, produção, transporte, importação e exportação desses produtos.

O Quadro 5 (ver Anexo) traz uma lista selecionada de decisões tomadas pelas agências desde 1999. Essas decisões endossam o postulado de que a Anatel e a ANP têm progredido satisfatoriamente desde então ao defenderem os consumidores finais, impondo multas, promovendo competição na medida do possível e de acordo com a respectiva base legal. Como exemplo de seu desempenho, pode-se falar da redefinição das regras concernentes à telefonia móvel em dezembro de 2000, situação que pôs em lados opostos as operadoras já em funcionamento e as novas empresas. Um segundo exemplo foi a imposição de multas às firmas que falharam na operação dos novos códigos de chamadas de longa distância em julho de 1999. Esse evento causou interrupções no sistema de telefonia, só completamente restabelecido cinco dias depois. A ANP também mostrou sua habilidade para mostrar suas garras. A agência ameaçou cassar as licenças de alguns postos de gasolina que estavam sendo acusados de cartelização, logo aumentando artificialmente seus preços ao consumidor. Talvez, o evento regulatório mais importante, até então, tenha sido a decisão de permitir à British Gas acesso (pago) ao gasoduto que transporta gás natural da Bolívia. A Petrobras é a maior acionista da companhia proprietária do gasoduto, até então sendo usado abaixo de sua capacidade máxima. A legislação regulatória previa que, em caso de capacidade ociosa no gasoduto, os competidores deveriam ter acesso possibilitado mediante o pagamento das taxas de acesso. Na condição de quase-monopólio, a Petrobras viu nisso uma ameaça aos seus negócios e recusou o acesso à British Gas, que por sua vez recorreu com sucesso à ANP contra a decisão. Não se deve negligenciar, contudo, o fato de que a Petrobras ameaçou recorrer da decisão da ANP à justiça, situação na qual uma confusão regulatória teria se seguido em detrimento à credibilidade do sistema.

$\mathrm{O}$ caso da Aneel é menos exitoso. A escassez de eletricidade que o país sofreu de março de 2001 a fevereiro de 2002 mostrou explicitamente a incapacidade da agência de estabelecer incentivos regulatórios para o setor e superar essa situação crítica. Tal fraqueza era tão evidente que o governo criou um "super-ministério" (Câmara de Gestão da Crise de Energia - CGCE) com o único fim de lidar com a questão. A Aneel perdeu temporariamente a maioria de suas prerrogativas regulatórias e o mercado à vista de eletricidade (spot) foi suspenso. A CGCE adotou medidas de emergência que provaram ser efetivas no equacionamento da crise. De fato, a CGCE substituiu a Aneel nessa questão. Houve rumores então de que a agência se fundiria com a ANP (criando uma agência de 
energia), e isso pode ser uma eventual solução em um futuro próximo.

Uma questão ainda não definida diz respeito a quanto as companhias de distribuição de eletricidade receberão de compensação pelas perdas causadas pela crise de energia, e em que horizonte de tempo isso aconteceria. Tentativas de desconsiderar a dívida, mesmo que justas, poderiam desacreditar ainda mais futuros investimentos no setor.

\section{Conclusão}

Os processos políticos identificados na criação e no desempenho das agências regulatórias vistos neste trabalho sugerem que o arranjo regulatório adotado pela Aneel é inepto para alcançar um ambiente regulatório razoável e crível. Sua incapacidade regulatória aumentou a incerteza da indústria do setor sobre que cartas estão na mesa. Isso foi tanto verdade que a administração federal não teve outra alternativa a não ser organizar uma autoridade regulatória ad hoc em maio de 2001 para tentar solucionar a escassez de eletricidade e os problemas dela decorrentes. Mesmo que tal medida excepcional tenha tido sucesso em consertar a situação, ela minou a credibilidade da agência. A influência política do Ministério das Minas e Energia no setor, a variável explicatória considerada neste trabalho, é interessante e merece mais pesquisa in loco com um trabalho de campo. Pode também ser o caso de quando um país põe em prática um sistema regulatório profundamente inconsistente com suas tradições políticas ou outras instituições, aquele tenderá a não funcionar a contento, e as tentativas de privatização e regulação podem terminar em recriminação e surgimento de demandas para renacionalização (Levy e Spiller, 1996). ${ }^{17}$

Outras questões não contempladas neste trabalho permanecem como itens a serem tratados em pesquisas futuras. Duas questões potencialmente conflitivas merecem ser mencionadas. Uma é a rivalidade entre as próprias agências (a Aneel e a ANP não deram uma resposta cooperativa à escassez de energia antes da comissão especial ser formada; a Anatel e a Aneel ainda não concordaram em como regular o uso dos postes de eletricidade a serem usados pelas companhias de telecomunicação; e o comportamento ainda não cooperativo das três agências vis-à-vis o Conselho Administrativo de Defesa Econômica — Cade). A segunda questão diz respeito à possibilidade de uma parte (consumidor ou empresa) não satisfeita com uma decisão tomada pela agência recorrer ao Judiciário e ter a decisão da agência suspensa ou anulada (como a Petrobras ameaçou fazer no caso da British Gas). Essa característica do sistema jurídico brasileiro só pode ser mudada por meio de uma emenda constitucional, representando nesse ínterim outra ameaça à credibilidade das agências. 
1 Artigo apresentado no I Congresso Latino-americano de Ciência Política, Salamanca, Espanha, de 9 a 11 de julho de 2002. Trata-se de parte de minha pesquisa de doutorado no Departamento de Governo na Universidade de Essex, Reino Unido. Gostaria de agradecer a Carlos Abdo Gaio, Fábio Soares, Todd Landman e especialmente Cinara Nahra pelos úteis comentários e sugestões. Omissões e erros, contudo, são exclusivamente de minha responsabilidade. Gostaria também de agradecer ao Departamento de Governo da Universidade de Essex pelo apoio financeiro para a viagem à Salamanca, e à Capes (Brasília, Brasil), pela bolsa de estudo que possibilita meu doutorado.

2 Existem nos seguintes Estados: Amazonas, Pará, Ceará, Rio Grande do Norte, Pernambuco, Alagoas, Sergipe, Bahia, Espírito Santo, Rio de Janeiro, São Paulo, Rio Grande do Sul, Goiás e Mato Grosso. A agência municipal localiza-se em Campo Grande, MS.

3 Constituição Federal, art. 25, §1.

4 Constituição Federal, art. 22, IV.

5 Apesar de a dupla regulação, por um lado, significar em teoria mais uma garantia ao governo e aos consumidores que as empresas estejam seguindo as regulações, por outro representa um fardo a mais em termos de custos e burocracia, e em alguns casos uma indefinição sobre a quem se recorrer.

6 Arranjo de sistema mais semelhante é uma tradução aproximada da técnica conhecida como Most Similar System Design (MSSD).

7 Esse é um típico problema de agente-principal: o principal (o consumidor) é menos informado do que o agente (o fornecedor) sobre as condições do comércio: qualidade e preço.

$8 \mathrm{Na}$ literatura anglo-saxã fala-se de tragedy of commons. A literatura jurídica brasileira cunhou o termo bem difuso. Essa espécie de bem tem as seguintes características: é supra-individual; seu objeto de interesse é indivisível; baseia-se em vínculos puramente fáticos e circunstanciais, e não de direito; pode acarretar lesões disseminadas em massa, haja vista a impossibilidade de se individualizar a vítima da lesão; e tem grande conflituosidade interna, traduzindo uma situação em que dificilmente será encontrada unanimidade entre os próprios interessados.

9 Apesar de o processo de privatização na administração de Fernando Henrique Cardoso poder ser considerado o mais importante em termos de número de empresas e o capital envolvidos, ele não pode ser considerado como a única leva de venda de estatais. Os presidentes Figueiredo (1979-1985), Sarney (1985-1989), Collor (1990-1992) e Itamar Franco (1992-1994) também privatizaram estatais. Cf. Quadro 2 (ver Anexo).

${ }^{10}$ Para uma crítica a Fiorina e Nichols, 1982.

${ }^{11}$ Leia-se política aqui como policy.

${ }^{12}$ O Brasil adota o princípio de representação proporcional sem cláusula de barreira para as eleições na Câmara dos Deputados, o que significa um número considerável de partidos.

${ }^{13}$ Pressões que foram responsáveis, por exemplo, pela exclusão das prerrogativas da Anatel, a regulação da radiodifusão e o direito de outorga de concessões de canais de rádio e televisão.

${ }^{14}$ A Anatel especifica um preço teto para uma cesta de serviços em telecomunicações. A Aneel determina um preço teto para as distribuidoras ao consumidor final, estabelece taxas de transmissão e deve monitorar os preços cobrados pela geradoras no atacado. A ANP controla os parâmetros que guiarão o aumento dos derivados de petróleo/gás natural até 31 de dezembro de 2001; a partir dessa data o mercado é livre (apesar da presença ainda quase monopolística da Petrobras). 
15 A Anatel é financiada por taxas pagas pelas companhias de telecomunicação (principalmente Fistel), que vai diretamente dessas àquela. A Aneel é financiada também por taxas pagas pelas companhias de eletricidade. A ANP financia-se pelo pagamento das taxas pagas pelas companhias de petróleo/gás natural ao vencerem os leilões dos campos de extração. Apesar de a maior parte dos recursos provir das fontes acima, as agências ainda têm dotação no orçamento federal.

${ }^{16} \mathrm{O}$ prazo pode ser antecipado se as empresas da área anteciparem as metas estabelecidas pela Anatel.

${ }_{17}$ Nem a escassez de eletricidade nem a confusão regulatória no setor levantaram vozes de renacionalização das companhias distribuidoras estaduais e geradoras. Contudo, tanto a venda como reorganização das companhias geradoras federais que deveriam acontecer no início de 2001 foram suspensas sine die.

\section{Referências bibliográficas}

Ayres, Ian; Braithwaite, John. (1992), Responsive Regulation. Transcending the Deregulation Debate. Oxford: Oxford University Press.

Baldwin, Robert; CAVE, Martin. (1999), Understanding Regulation. Theory. Strategy and Practice. Oxford: Oxford University Press.

Baldwin, Robert; Scott, Colin; Hood, Christopher. (1998), A Reader on Regulation . Oxford: Oxford University Press.

Bardach, Eugene; Kagan, Robert A. (1982), Going by the Book. The Problem of Regulatory Unreasonableness. Philadelphia: Temple University Press.

BernsteIn, Marver H. (1966), Regulating Business by Independent Commission. Princeton (NJ): Princeton University Press, (1955).

Brasil. Presidência da República.(1995), Plano Diretor da Reforma do Aparelho do Estado. Brasília: Imprensa Nacional.

Bresser Pereira, Luiz Carlos. (1998a), Reforma do Estado para a Cidadania: A Reforma Gerencial Brasileira na Perspectiva Internacional. São Paulo: Ed. 34/ENAP. . (1998b), "Uma reforma gerencial da Administração Pública no Brasil". Revista do Serviço Público, Brasília, ano 49, no 1, jun-mar.

BREYER, Stephen. (1990), "Regulation and Deregulation in the United States: Airlines, Telecommunications and Antitrust", in MAJone, Giandomenico (ed.), Deregulation or Reregulation? Regulatory reform in Europe and in the United States. London: Pinter Publishers.

CARneIro, Francisco Galrão; Rocha, Carlos Henrique. (1999), "Reforming the Public Sector in Latin America: a cross-country perspective", in PInHeIro, Armando Castelar; Fukasaku, Kiichiro (eds.), Privatisation in Brazil: the case of public utilities. Rio de Janeiro: BNDES.

Clarke, Michael. (2000), Regulation: the Social Control of Business between Law and Politics. London: MacMillan Press.

CoOpers \& Lybrand. (1997a), Electricity Sector Restructuring Project. Stage IV. Draft Consolidated Report IV-1. Volume 1. Executive Summary. Brasília: mimeo.

. (1997b), "Privatization Policy”. Working Paper D2, Brasília: mimeo. 
EIsNER, Marc Allen. (2000), Regulatory Politics in Transition. Baltimore (Maryland): Johns Hopkins University Press.

FioRINA, Morris P. (1982), "Legislative Choice of Regulatory Forms: Legal Process or Administrative Process?". Public Choice 39, p. 33-66.

Francis, John. (1993), The Politics of Regulation. A Comparative Perspective. Blackwell: Oxford.

Hancher, Leigh; Moran, Michael. (1989), "Conclusion”, in Hancher, Leigh; Moran, Michael (ed.), Capitalism, Culture, and Economic Regulation. Oxford: Oxford University Press.

Hardin, G. (1968), "The Tragedy of the Commons". Science 162, p. 1243-8

Harris, Richard A., Mirkis, Sidney M. (1989), The Politics of Regulatory Change. A Tale of Two Agencies. Oxford: Oxford University Press.

Helm, Dieter; Jenkinson, Tim. (1997), “The Assessment: Introducing Competition into Regulated Industries". Oxford Review of Economic Policy 13 (1), p. 1-14.

HזL, Alice; AbDala, Manuel Angel. (1996), “Argentina: the sequencing of privatisation and regulation", in LevY, Brian; SPLLer, Pablo T. (eds.), Regulations, Institutions and Commitment. Comparative Studies of Telecommunications. Cambridge: Cambridge University Press.

KAY, John; VICKERS, John. (1990), "Regulatory Reform: an Appraisal", in MAJONE, Giandomenico (ed.), Deregulation or Reregulation? Regulatory reform in Europe and in the United States. London: Pinter Publishers.

King, Gary; Keohane, Robert O., Verba, Sidney. (1994), Designing Social Enquiry. Princeton (NJ): Princeton University Press.

Landman, Todd. (2000), Issues and Methods in Comparative Politics. London: Routledge.

Levy, Brian; SpiLler, Pablo T. (eds.) (1996), Regulations, Institutions and Commitment. Comparative Studies of Telecommunications. Cambridge: Cambridge University Press.

Linhares Pires, José Cláudio; Goldstein, Andrea. (2001), "Agências Reguladoras Brasileiras: Avaliação e Desafios". Revista do BNDES, vol. 8, nº 16, dezembro.

McCubBins et al. (1987), "Administrative Procedures as Instruments of Political Control". Journal of Law, Economics and Organisations 3(2), p. 243-77.

Majone, Giandomenico. (1990), "Introduction”, in Majone, Giandomenico (ed). Deregulation or Reregulation? Regulatory reform in Europe and in the United States. London: Pinter Publishers.

(1996a), "Regulation and its modes", in MAJONE, Giandomenico (ed.), Regulating Europe. London: Routledge.

. (1996b), "The rise of statutory regulation in Europe", in MAJONE Giandomenico (ed.), Regulating Europe. London: Routledge.

ManzetTI, Luigi. (2000), "Latin American Regulatory Policies in the Post-Privatization Era", in MAnzetti, Luigi (ed.), Regulatory Policy in Latin America: Post-Privatization Realities. Coral Gables: North-South Center Press.

MAYER, Colin. (2001), "The Design of Regulatory Institutions". Paper presented at the Seminar Competition and Regulation: The Energy Sector in Brazil and the UK/EU, held at the Centre for Brazilian Studies at the University of Oxford (St. Anne's College), Oxford, 4 e 5 de junho.

MeIER, Kenneth J. (1985), Regulation. Politics, Bureaucracy, and Economics. New York: St. Martin's Press.

Moran, Michael. (1989), "Investor Protection and the Culture of Capitalism", in Hancher, Leigh; Moran, Michael (ed.), Capitalism, Culture, and Economic Regulation. Oxford: Oxford University Press.

Moran, Michael; Prosser, Tony. (1994), "Introduction: Politics, Privatization and Constitutions", in Moran, Michael; Prosser, Tony (eds.), Privatization and Regulatory Change in Europe. Buckingham: Open University Press. 
Mueller, Bernardo. (2001), "Institutions for Commitment in the Brazilian regulatory system". The Quarterly Review of Economics and Finance 41, p. 621-643.

Navarro, Peter. (1985), The Dimming of America. The Real Costs of Electricity Utility Regulatory Failure. Cambridge (Massachusetts): Ballinger Publishing Company.

Nichols, Albert. (1982), "Legislative Choice of Regulatory Forms". Public Choice 39, p. 67-70.

Niskanen, William A. (1968), "The Peculiar Economics of Bureaucracy". American Economic Review Papers and Procedings 58, p. 293-305.

O Estado de São Paulo. (2001a), "FHC quer concluir trabalho de Sérgio Motta". 23 de dezembro de 2001.

(2001b), “Anatel quer resgatar projeto de Motta”. 17 de julho de 2001.

PeCl, Alketa. Novo Marco Regulatório para o Brasil da Pós-Privatização; o Papel das Agencias Reguladoras em Questão. Manuscript, $\mathrm{n} / \mathrm{d}$.

Ostrom, Elinor. (1994), Governing the Commons. The Evolution of Institutions for Collective Action. Cambridge: Cambridge University Press.

OSTROM, Elinor; W ALKER, James. (1997), "Neither markets nor states: linking transformations processes in collective action arenas", in Mueller, Dennis C., Perspectives on public choice. A Handbook. Cambridge: Cambridge University Press.

Pereira, Carlos; Mueller, Bernardo. (2001), "Credibility and the Design of Regulatory Agencies in Brazil". Paper presented at the Seminar Competition and Regulation: The Energy Sector in Brazil and the UK/EU, held at the Centre for Brazilian Studies at the University of Oxford (St. Anne's College), Oxford, 4 e 5 de junho.

Pires, José Cláudio Linhares; GoldSTEIN, Andrea. (2001), "Agências Reguladoras Brasileiras: Avaliação e Desafios". Revista do BNDES, v. 8, no 16.

Prosser, Tony. (1989), "Regulation of Privatised Enterprises: Institutions and Procedures", in Hancher, Leigh; Moran, Michael (ed.), Capitalism, Culture, and Economic Regulation . Oxford: Oxford University Press.

QuiRK, Paul J. (1981), Industry Influence in Federal Regulatory Agencies. Princeton (NJ): Princeton University Press.

SAntos, Anibal. (1990), "Privatization and State Intervention (An Economic Approach)", in MAJone, Giandomenico (ed.), Deregulation or Reregulation? Regulatory reform in Europe and in the United States. London: Pinter Publishers.

S Appington, David E. M., Stiglitz, Joseph. (1987), "Information and Regulation", in BAIley, Elizabeth E. (ed.), Public Regulation, New Perspectives on Institutions and Policies. Cambridge (Massachusetts): The MIT Press.

Selznick, P. (1985), "Focusing Organizational Research on Regulation", in Noll, R. (ed.), Regulatory Policy and the Social Sciences. Berkeley: University of California Press.

VICKERS, John; YARRow, George. (1989), Privatization: An Economic Analysis. Cambridge (Massachusetts): The MIT Press.

Viscusi, W. Kip; Vernon, John M., Harrington JR., Joseph E. (2000), Economics of Regulation and Antitrust. Cambridge (Massachusetts.): The MIT Press.

Wellenius, Bjorn. (2000), "Regulating the Telecommunications Sector: The Experience of Latin America", in Manzetti, Luigi (ed.), Regulatory Policy in Latin America: PostPrivatization Realities. Coral Gables: North-South Center Press.

Weyman-Jones, Tom. (1994), "Deregulation", in Jackson, Peter M., Price, Catherine M., Privatisation and regulation: a review of the issues. New York: Longman Group Limited. WILSON, James Q. (1989), Bureacracy: What government agencies do and why they do it. New York: Basic Books.

Wintrobe, Ronald. (1997), "Modern bureaucratic theory", in Mueller, Dennis C. (ed.), Perspectives in Public Choice: a handbook. Cambridge: Cambridge University Press. 
Quadro 1: Arranjo de sistema mais semelhante (MSSD) aplicado aos três casos

\begin{tabular}{l|c|c|c}
\hline & \multicolumn{3}{|c}{ Arranjo de sistema mais semelhante } \\
\hline & $\operatorname{Caso} \alpha$ & $\operatorname{Caso} \beta$ & Caso $\delta$ \\
\hline Característica a & $\operatorname{Sim}$ & $\operatorname{Sim}$ & $\operatorname{Sim}$ \\
\hline Característica b & $\operatorname{Sim}$ & $\operatorname{Sim}$ & $\operatorname{Sim}$ \\
\hline $\begin{array}{l}\text { Característica c } \\
\text { (fator explicativo chave) }\end{array}$ & $\operatorname{Sim}$ & $\operatorname{Sim}$ & Não \\
\hline $\begin{array}{l}\text { Resultado a ser explicado } \\
\text { (sucesso da agência) }\end{array}$ & $\mathrm{X}$ & $\mathrm{X}$ & Não X \\
\hline
\end{tabular}

Fonte: Adaptado da tabela original em Landman, 2000.

Quadro 2: “Ondas” de privatização no Brasil, 1981-2002

\begin{tabular}{l|l|l|l}
\hline Fase & Período & Presidente & Setores privatizados \\
\hline I & $1981-1989$ & Figueiredo e Sarney & Vários \\
\hline II & $1990-1992$ & Collor & $\begin{array}{l}\text { Siderurgia, petroquímicos, } \\
\text { fertilizantes }\end{array}$ \\
\hline III & $1992-1994$ & Itamar Franco & $\begin{array}{l}\text { Siderurgia, petroquímicos, } \\
\text { fertilizantes }\end{array}$ \\
\hline IV & $1995-2002$ & $\begin{array}{l}\text { Fernando Henrique } \\
\text { Cardoso }\end{array}$ & $\begin{array}{l}\text { Petroquímicos, eletricidade } \\
\text { (companhias de distribuição), } \\
\text { telecomunicações, bancos } \\
\text { (bancos estaduais } \\
\text { federalizados) }\end{array}$ \\
\hline
\end{tabular}

Elaboração do autor. 
Quadro 3: Reforma do Estado no Brasil, 1995

\begin{tabular}{|c|c|c|c|c|c|}
\hline & \multicolumn{3}{|c|}{ Forma de propriedade } & \multicolumn{2}{|c|}{ Forma de administração } \\
\hline & Estatal & $\begin{array}{l}\text { Pública não } \\
\text { estatal }\end{array}$ & Privada & Burocrática & Gerencial \\
\hline $\begin{array}{l}\text { Núcleo estratégico } \\
\text { (Legislativo, Judiciário, } \\
\text { presidência, cúpula } \\
\text { dos ministérios e } \\
\text { Ministério Público) }\end{array}$ & & & & & \\
\hline $\begin{array}{l}\text { Atividades exclusivas } \\
\text { (regulamentação, } \\
\text { fiscalização, fomento, } \\
\text { segurança pública e } \\
\text { seguridade social básica) }\end{array}$ & & & & & \\
\hline $\begin{array}{l}\text { Serviços não-exclusivos } \\
\text { (universidades, hospitais, } \\
\text { centros de pesquisa) }\end{array}$ & & $\rightarrow$ & & & \\
\hline $\begin{array}{l}\text { Produção para o mercado } \\
\text { (empresas estatais) }\end{array}$ & & & $\rightarrow$ & & \\
\hline
\end{tabular}

Fonte: Brasil, 1995.

Quadro 4: Anatel, Aneel e ANP: dimensões-chave

\begin{tabular}{|c|c|c|c|}
\hline & Anatel & Aneel & ANP \\
\hline Ato fundante & $\begin{array}{l}\text { Lei no } 9.472 \text { de julho de } \\
\text { 1997, decreto } \text { n }^{\circ} 2.338 \\
\text { de dezembro de } 1997\end{array}$ & $\begin{array}{l}\text { Lei } n^{\circ} 9.427 \text { de dezem- } \\
\text { bro de } 1996 \text {, decreto } \\
n^{0} 2.335 \text { de outubro } \\
\text { de } 1997\end{array}$ & $\begin{array}{l}\text { Lei no } 9.478 \text { de } \\
\text { agosto de } 1997 \text {, } \\
\text { decreto no } 2.455 \text { de } \\
\text { Janeiro de } 1998\end{array}$ \\
\hline Status jurídico & $\begin{array}{l}\text { Autarquia de } \\
\text { natureza especial }\end{array}$ & $\begin{array}{l}\text { Autarquia de } \\
\text { natureza especial }\end{array}$ & $\begin{array}{l}\text { Autarquia de } \\
\text { natureza especial }\end{array}$ \\
\hline $\begin{array}{l}\text { Situação do } \\
\text { setor antes da } \\
\text { privatização }\end{array}$ & $\begin{array}{l}\text { Telebrás como holding } \\
\text { estatal e monopolista }\end{array}$ & $\begin{array}{l}\text { Eletrobrás como } \\
\text { holding e virtualmente } \\
\text { monopolista na geração } \\
\text { e transmissão; empresas } \\
\text { estaduais responsáveis } \\
\text { pela distribuição e } \\
\text { comercialização }\end{array}$ & $\begin{array}{l}\text { Petrobras como } \\
\text { monopolista na } \\
\text { extração, exporta- } \\
\text { ção e importação de } \\
\text { petróleo; Petrobras é } \\
\text { a maior empresa no } \\
\text { refino e transporte; } \\
\text { mercado competi- } \\
\text { tivo e aberto na } \\
\text { comercialização } \\
\end{array}$ \\
\hline Conselho Diretor & $\begin{array}{l}\text { Diretor-presidente } \\
\text { e quatro diretores. } \\
\text { O poder de nomear é } \\
\text { prerrogativa do Presi- } \\
\text { dente da República, com } \\
\text { a aprovação do Senado. } \\
\text { Nenhuma conexão } \\
\text { com o setor é permiti- } \\
\text { da, mandatos de cinco } \\
\text { anos não coincidentes } \\
\text { (primeiros mandatos }\end{array}$ & $\begin{array}{l}\text { Diretor-presidente } \\
\text { e quatro diretores. } \\
\text { O poder de nomear } \\
\text { é prerrogativa do } \\
\text { Presidente da Repú- } \\
\text { blica, com a aprovação } \\
\text { do Senado. Nenhuma } \\
\text { conexão com o setor } \\
\text { é permitida, mandatos } \\
\text { de quatro anos não } \\
\text { coincidentes primeiros }\end{array}$ & $\begin{array}{l}\text { Diretor-presidente } \\
\text { e quatro diretores. } \\
\text { O poder de nomear } \\
\text { é prerrogativa do } \\
\text { Presidente da Repú- } \\
\text { blica, com a apro- } \\
\text { vação do Senado. } \\
\text { Nenhuma conexão } \\
\text { com o setor é per- } \\
\text { mitida, mandatos }\end{array}$ \\
\hline
\end{tabular}




\begin{tabular}{|c|c|c|c|}
\hline & $\begin{array}{l}\text { excepcionalmente mais } \\
\text { longos para satisfazer } \\
\text { essa condição), estabili- } \\
\text { dade no cargo durante o } \\
\text { mandato (a não ser em } \\
\text { caso de justa causa e } \\
\text { mesmo assim só o } \\
\text { Senado pode fazê-lo), } \\
\text { quarentena de } 12 \text { meses } \\
\text { (exceto para tornar-se } \\
\text { docente) }\end{array}$ & $\begin{array}{l}\text { (primeiros mandatos } \\
\text { excepcionalmente } \\
\text { mais longos para satis- } \\
\text { fazer essa condição), } \\
12 \text { meses de quaren- } \\
\text { tena; estabilidade no } \\
\text { cargo durante o } \\
\text { mandato (a não ser } \\
\text { em caso de justa causa, } \\
\text { e mesmo assim só o } \\
\text { Senado pode fazê-lo) }\end{array}$ & $\begin{array}{l}\text { de quatro anos não } \\
\text { coincidentes (pri- } \\
\text { meiros mandatos } \\
\text { excepcionalmente } \\
\text { mais longos para } \\
\text { satisfazer essa con- } \\
\text { dição), } 12 \text { meses de } \\
\text { quarentena; estabili- } \\
\text { dade no cargo } \\
\text { durante o mandato } \\
\text { (a não ser em caso } \\
\text { de justa causa, e } \\
\text { mesmo assim só o } \\
\text { Senado pode fazê-lo) }\end{array}$ \\
\hline $\begin{array}{l}\text { Fontes de } \\
\text { financiamento }\end{array}$ & $\begin{array}{l}\text { Fistel, orçamento, } \\
\text { multas }\end{array}$ & $\begin{array}{l}\text { Taxa de fiscalização } \\
\text { de Serviços de Energia } \\
\text { Elétrica, orçamento, } \\
\text { multas }\end{array}$ & $\begin{array}{l}\text { Diversas fontes, } \\
\text { orçamento, multas }\end{array}$ \\
\hline $\begin{array}{l}\text { Tarifação dos } \\
\text { setores regulados }\end{array}$ & $\begin{array}{l}\text { Teto de preço para } \\
\text { uma cesta de serviços } \\
\text { básicos }\end{array}$ & $\begin{array}{l}\text { Teto de preço para } \\
\text { as distribuidoras no } \\
\text { varejo; estabelece as } \\
\text { taxas de transmissão, } \\
\text { deve monitorar os } \\
\text { preços no atacado } \\
\text { cobrados pelas gera- } \\
\text { doras }\end{array}$ & $\begin{array}{l}\text { A ANP controla os } \\
\text { parâmetros que guia- } \\
\text { rão os aumentos dos } \\
\text { derivados de petró- } \\
\text { leo/gás natural até } \\
31 \text { de dezembro de } \\
\text { 2001. A partir dessa } \\
\text { data os preços são } \\
\text { livres. }\end{array}$ \\
\hline $\begin{array}{l}\text { Papel dos } \\
\text { ministérios } \\
\text { durante a criação } \\
\text { da agência }\end{array}$ & $\begin{array}{l}\text { Ministério das Comuni- } \\
\text { cações, pertencente à } \\
\text { chamada "quota } \\
\text { pessoal" do presidente. } \\
\text { Arranjo regulatório } \\
\text { criado com menos } \\
\text { restrições partidárias. } \\
\text { Ao final do processo, } \\
\text { tal ministério deveria } \\
\text { ser extinto. }\end{array}$ & $\begin{array}{l}\text { Ministério das Minas } \\
\text { e Energia, pertencente } \\
\text { à chamada "quota } \\
\text { partidária". Arranjo } \\
\text { regulatório criado } \\
\text { com grande influência } \\
\text { partidária }\end{array}$ & $\begin{array}{l}\text { Ministério das Minas } \\
\text { e Energia, perten- } \\
\text { cente à chamada } \\
\text { "quota partidária". } \\
\text { Contudo, diferente- } \\
\text { mente da Aneel e } \\
\text { apesar da Petrobras, } \\
\text { o arranjo regulatório } \\
\text { foi criado com menos } \\
\text { influências partidárias }\end{array}$ \\
\hline $\begin{array}{l}\text { Situação do setor } \\
\text { após a } \\
\text { privatização }\end{array}$ & $\begin{array}{l}\text { Duopólio para os servi- } \\
\text { ços fixos até } 2002 \text {, } \\
\text { quatro operadoras hábeis } \\
\text { a oferecer chamadas } \\
\text { intra-regionais até } 2002 \text {; } \\
\text { duopólio para serviços } \\
\text { inter-regionais e interna- } \\
\text { cionais até } 2002 \text {; duopó- } \\
\text { lio para serviços móveis } \\
\text { até } 2001 \text {. Contanto que } \\
\text { as metas das firmas que } \\
\text { já estavam no mercado } \\
\text { sejam cumpridas } \\
\text { (incumbent), elas podem } \\
\text { ter acesso a outras } \\
\text { áreas. É favorecido um } \\
\text { ambiente competitivo }\end{array}$ & $\begin{array}{l}\text { Privatização da maio- } \\
\text { ria das distribuidoras } \\
\text { estaduais; privatização } \\
\text { de algumas geradoras e } \\
\text { linhas de transmissão; } \\
\text { privatização das } \\
\text { geradoras federais } \\
\text { adiada sine die: } \\
\text { competição não } \\
\text { é favorecida }\end{array}$ & $\begin{array}{l}\text { Monopólio da } \\
\text { Petrobras foi } \\
\text { quebrado na explo- } \\
\text { ração, produção, } \\
\text { importação e expor- } \\
\text { tação, apesar de a } \\
\text { empresa não ter } \\
\text { sido privatizada: } \\
\text { competição } \\
\text { engatinha, mas } \\
\text { é favorecida }\end{array}$ \\
\hline
\end{tabular}

Fonte: As leis e decretos citados (Pereira e Mueller, 2001). 
Quadro 5: Decisões selecionadas tomadas

pela Anatel, Aneel e ANP, 1998-2001

\begin{tabular}{|c|c|c|c|c|}
\hline Evento & & $\begin{array}{l}\text { Avaliação subje- } \\
\text { tiva da decisão }\end{array}$ & $\begin{array}{l}\text { Avaliação subje- } \\
\text { tiva da decisão } \\
\text { (adequação a } \\
\text { determinações } \\
\text { contratuais) }\end{array}$ & $\begin{array}{l}\text { Outras } \\
\text { características }\end{array}$ \\
\hline \multicolumn{5}{|l|}{ Anatel } \\
\hline Venda de ações & $\begin{array}{l}\text { Intervenção na } \\
\text { diretoria da CRT } \\
\text { (junho de } 2000 \text { a } \\
\text { junho de 2001) }\end{array}$ & $\begin{array}{l}\text { Correta } \\
\text { para evitar } \\
\text { concentração } \\
\text { no mercado }\end{array}$ & $\begin{array}{l}\text { Adequada, } \\
\text { aplicando a } \\
\text { lei no } 9.472\end{array}$ & $\begin{array}{l}\text { Apelação } \\
\text { ao Judiciário }\end{array}$ \\
\hline $\begin{array}{l}\text { Redefinição das } \\
\text { regras da tele- } \\
\text { fonia móvel }\end{array}$ & $\begin{array}{l}\text { Resolução n̊ } \\
253 \text {, dezembro } \\
\text { de } 2000\end{array}$ & Correta & $\begin{array}{l}\text { Adequada, apli- } \\
\text { cando o decreto } \\
\text { n⿳ } 2.534\end{array}$ & $\begin{array}{l}\text { Conflito entre } \\
\text { empresas novas e } \\
\text { em operação }\end{array}$ \\
\hline Multas & $\begin{array}{l}\text { Total falha } \\
\text { no sistema de } \\
\text { chamada de } \\
\text { longa distância } \\
\text { por mais de } 24 \\
\text { horas; restabe- } \\
\text { lecimento total } \\
\text { depois de cinco } \\
\text { dias, julho } 1999\end{array}$ & Correta & $\begin{array}{l}\text { Adequada, } \\
\text { aplicando a lei } \\
\mathrm{n}^{0} 9.472\end{array}$ & $\begin{array}{l}\text { As empresas } \\
\text { ameaçaram apelar } \\
\text { ao Judiciário, mas } \\
\text { desistiram }\end{array}$ \\
\hline Metas & $\begin{array}{l}\text { Monitoramento } \\
\text { para o cumpri- } \\
\text { mento das metas } \\
\text { estabelecidas nos } \\
\text { contratos e na lei }\end{array}$ & Correta & $\begin{array}{l}\text { Adequada, } \\
\text { aplicando o } \\
\text { decreto } n^{\circ} \\
2.592 \text { e a lei } \\
\text { no } 9.472 \\
\end{array}$ & \\
\hline $\begin{array}{l}\text { Competência } \\
\text { quanto à radio- } \\
\text { difusão }\end{array}$ & $\begin{array}{l}\text { Direito de } \\
\text { conceder licen- } \\
\text { ças de radiodifu- } \\
\text { são }\end{array}$ & $\begin{array}{l}\text { Deveria ser da } \\
\text { Anatel, mas } \\
\text { Ministério das } \\
\text { Comunicações } \\
\text { quis manter tal } \\
\text { prerrogativa }\end{array}$ & $\begin{array}{l}\text { Ainda em } \\
\text { discussão no } \\
\text { Congresso }\end{array}$ & \\
\hline \multicolumn{5}{|l|}{ ANP } \\
\hline $\begin{array}{l}\text { Leilão das } \\
\text { Offer for bid } \\
\text { of petroleum } \\
\text { and natural } \\
\text { gas field, on } \\
\text { and off-shore }\end{array}$ & $\begin{array}{l}\text { Oferta pública, } \\
\text { várias “ondas" } \\
\text { (junho de } 1999, \\
\text { junho de } 2000, \\
\text { junho de 2001) }\end{array}$ & $\begin{array}{l}\text { Correta, } \\
\text { promoção da } \\
\text { competição }\end{array}$ & $\begin{array}{l}\text { Adequada, } \\
\text { aplicando a } \\
\text { lei } n^{\circ} 9.478 \\
\text { e o decreto } \\
\text { n- } 2.455\end{array}$ & $\begin{array}{l}\text { Temor que a } \\
\text { Petrobras daria } \\
\text { o maior lance } \\
\text { para manter-se } \\
\text { na condição de } \\
\text { monopolista }\end{array}$ \\
\hline $\begin{array}{l}\text { Cassação } \\
\text { de licenças } \\
\text { de postos de } \\
\text { combustível }\end{array}$ & $\begin{array}{l}\text { Resolution 26, } \\
\text { dezembro } \\
\text { de } 2000\end{array}$ & $\begin{array}{l}\text { Correta, bené- } \\
\text { fica aos consu- } \\
\text { midores finais }\end{array}$ & Adequada & $\begin{array}{l}\text { Ameaça de recorrer } \\
\text { ao Judiciário }\end{array}$ \\
\hline
\end{tabular}

(continua) 


\begin{tabular}{|c|c|c|c|c|}
\hline $\begin{array}{l}\text { Acesso } \\
\text { ao gasoduto } \\
\text { Bolívia- } \\
\text { Brasil }\end{array}$ & $\begin{array}{l}\text { Decreto } n^{\circ} 8 \\
\left(\text { lei } n^{\circ} 9.478\right)\end{array}$ & $\begin{array}{l}\text { Correta, mas } \\
\text { insuficiente se } \\
\text { o objetivo é } \\
\text { promoção da } \\
\text { competição }\end{array}$ & $\begin{array}{l}\text { Insuficiente. } \\
\text { Decisão } \\
\text { precária }\end{array}$ & $\begin{array}{l}\text { Foi a ameaça mais } \\
\text { crível de recurso } \\
\text { ao judiciário, mas } \\
\text { dessa vez a Petro- } \\
\text { bras seria a autora } \\
\text { e a ANP e a BG } \\
\text { seriam rés. Desis- } \\
\text { tência de prosse- } \\
\text { guir na ameaça }\end{array}$ \\
\hline Importação & $\begin{array}{l}\text { ANP autoriza } \\
\text { outras compa- } \\
\text { nhias a importar } \\
\text { combustível }\end{array}$ & $\begin{array}{l}\text { Correta, dimi- } \\
\text { nuindo o poder } \\
\text { de mercado da } \\
\text { Petrobras }\end{array}$ & Adequada & \\
\hline $\begin{array}{l}\text { Compra } \\
\text { de ações }\end{array}$ & $\begin{array}{l}\text { Se a Petrobras } \\
\text { comprar ações } \\
\text { de uma subsidiá- } \\
\text { ria da Enron, ela } \\
\text { deve vender } 2 \% \\
\text { de suas ações } \\
\text { em gasoduto }\end{array}$ & $\begin{array}{l}\text { Correta, preve- } \\
\text { nindo concen- } \\
\text { tração de } \\
\text { mercado }\end{array}$ & $\begin{array}{l}\text { Adequada e } \\
\text { conforme o } \\
\text { CADE }\end{array}$ & $\begin{array}{l}\text { Compra ainda não } \\
\text { formalizada }\end{array}$ \\
\hline \multicolumn{5}{|l|}{ Aneel } \\
\hline $\begin{array}{l}\text { Intervenção } \\
\text { no mercado } \\
\text { spot }\end{array}$ & $\begin{array}{l}\text { Resoluções } 160 \text {, } \\
161 \text { e } 162 \text {, abril } \\
\text { de } 2001\end{array}$ & $\begin{array}{l}\text { Correta, mas } \\
\text { muito pouco, } \\
\text { muito tarde }\end{array}$ & Precária & $\begin{array}{l}\text { Ameaça de apelo } \\
\text { ao Judiciário }\end{array}$ \\
\hline $\begin{array}{l}\text { Escassez de } \\
\text { eletricidade }\end{array}$ & $\begin{array}{l}\text { Competências } \\
\text { perdidas para a } \\
\text { CGCE }\end{array}$ & $\begin{array}{l}\text { Muito pouco, } \\
\text { muito tarde; } \\
\text { negativa para } \\
\text { a agência } \\
\text { regulatória }\end{array}$ & $\begin{array}{l}\text { Novas } \\
\text { regulações } \\
\text { enfraquecem } \\
\text { a Aneel }\end{array}$ & $\begin{array}{l}\text { Ameaça de recurso } \\
\text { ao Judiciário. } \\
\text { Superior Tribunal } \\
\text { Federal decidiu pela } \\
\text { constitucionalidade } \\
\text { das medidas }\end{array}$ \\
\hline Anexo $5^{*}$ & $\begin{array}{l}\text { Indenizações (a } \\
\text { serem pagas às } \\
\text { distribuidoras) } \\
\text { dada a escassez } \\
\text { de eletricidade }\end{array}$ & $\begin{array}{l}\text { Reconheci- } \\
\text { mento do } \\
\text { débito como } \\
\text { uma demanda } \\
\text { justa, mas } \\
\text { decisão sobre a } \\
\text { quantia ainda } \\
\text { não tomada. } \\
\text { Mau para o } \\
\text { setor e para } \\
\text { Agência, uma } \\
\text { vez que dá } \\
\text { impressão } \\
\text { de inação ou } \\
\text { omissão }\end{array}$ & $\begin{array}{l}\text { Adequada no } \\
\text { reconhecimento } \\
\text { do débito à luz } \\
\text { dos contratos }\end{array}$ & $\begin{array}{l}\text { Ameaça de recurso } \\
\text { ao Judiciário }\end{array}$ \\
\hline Multas & $\begin{array}{l}\text { Furnas multadas } \\
\text { em setembro de } \\
2000\end{array}$ & Correta & Correta & $\begin{array}{l}\text { Até então, a gera- } \\
\text { dora não efetuou } \\
\text { pagamento }\end{array}$ \\
\hline
\end{tabular}

* Anexo de contratos de licitação que prevê ressarcimento às distribuidoras em caso de mudança nas condições financeiro-econômicas das mesmas, o mesmo que aconteceu com o racionamento.

Fonte: Linhares e Goldstein, 2001. Com material adicional de artigos da Folha de São Paulo e de O Estado de São Paulo. 


\section{Agências regulatórias no Brasil: os casos dos setores de telecomunicações, eletricidade e petróleo/gás natural \\ Marcelo Gameiro de Moura}

Este artigo é um estudo comparativo tanto da criação das agências regulatórias para as telecomunicações, eletricidade e petróleo/gás natural: Agência Nacional de Telecomunicações (Anatel), Agência Nacional de Energia Elétrica (Aneel) e Agência Nacional do Petróleo (ANP) como de seu desempenho desde 1998. Mais importante, será mostrado neste artigo que a Anatel e a ANP têm desempenhado seus papéis de acordo com as "expectativas" (de promover competição e a defesa dos consumidores) e que a Aneel tem falhado nessa tarefa por conta da ausência de um fator-chave presente nas outras duas. $\mathrm{O}$ artigo está estruturado da seguinte forma. A segunda seção lida com aspectos metodológicos da pesquisa: a justificação dos casos selecionados e a apresentação das variáveis-chave com as quais as agências serão comparadas. A terceira seção trata a questão da regulação em geral, apresentando uma breve análise histórica do assunto, as rationales e problemas da regulação, a reforma regulatória e os tipos de reguladores. A quarta e última parte do artigo lida com a situação regulatória no Brasil: a situação pré-1997, o estabelecimento de agências regulatórias no país, e as situações enfrentadas pelas três agências desde 1999.

\section{Agencias reguladoras en Brasil: los casos de los sectores de telecomunicaciones, electricidad y petróleo/gas natural}

Marcelo Gameiro de Moura

Este artículo es un estudio comparativo tanto sobre la creación de agencias reguladoras de telecomunicaciones, electricidad, y aceite/gas natural: Agencia Nacional de Telecomunicaciones (Agência Nacional de Telecomunicações - Anatel); Agencia Nacional de Electricidad (Agência Nacional de Energia Elétrica - Aneel); y Agencia Nacional de Petroleo (Agência Nacional de Petróleo - ANP) respectivamente, como sobre su actuación desde 1998. Concretamente, en el artículo se destacará que Anatel y ANP han actuado de acuerdo a las "expectativas" (acerca de promover la competencia y la protección de los usuarios) y que Aneel no lo ha conseguido por carecer del factor clave explicativo presente en las otras dos agencias. El artículo se estructura como sigue. La siguiente sección se ocupa de los aspectos metodológicos de la investigación: justificación de los casos seleccionados y presentación de las variables clave con las que se compararán las agencias. La tercera sección aborda aspectos de la regulación en general, ofreciendo una breve perspectiva histórica en la materia, los fundamentos y problemas con la regulación, la reforma reguladora y tipos de reguladores. La cuarta y última parte del artículo se ocupa de la situación reguladora en Brasil: la situación pre-1997, el establecimiento de las agencias reguladoras en el país, y los aspectos clave afrontados por las agencias desde 1999.

\section{Regulatory agencies in Brazil: the cases of telecom, electricity and oil sectors Marcelo Gameiro de Moura}

This paper is a comparative study on both the creation of regulatory agencies for telecommunications, electricity, and oil/natural gas: National Agency for Telecommunications (Agência Nacional de Telecomunicações - Anatel); National Agency for Electricity (Agência Nacional de Energia Elétrica - Aneel); and National Agency for Petroleum (Agência Nacional do Petróleo - ANP) respectively and how they have performed since 1998. More importantly, the paper will argue that the Anatel and ANP
Revista do

Serviço

Público

Ano 53

Número 2

Abr-Jun 2002

Marcelo

Gameiro de Moura é mestre em Ciência Política pela Universidade de Brasília (UnB); e pela

Universidade de Essex, Reino Unido, é mestre em Governo e Política Latinoamericanos e doutorando em Ciência Política.

Contato: mgamei@ essex.ac.uk 
have performed according to "expectations" (of promoting competition and the protection of the users) and that Aneel has failed to do so because of the absence of a key explanatory factor that was present at the other two. The paper is structured as follows. The next section deals with the methodological aspects of the research: justification of the selected cases and the presentation of the key variables with which the agencies are going to be compared. The third section deals with the issue of regulation in general, giving a very brief historical perspective on the issue, the rationales and problems with regulation, the regulatory reform and types of regulators. The fourth and final part of the paper deals with the regulatory situation in Brazil: the situation pre-1997, the establishment of the regulatory agencies in the country, and key issues faced by the three agencies since 1999. 